\title{
АНАЛИЗА СТЕПЕНА ТЕЖИНЕ УЏБЕНИЧКОГ ТЕКСТА ТЕОЛОГИЈЕ НА ЕНГЛЕСКОМ И СРПСКОМ ЈЕЗИКУ
}

\section{Сажетак}

Овим радом настојали смо да утврдимо степен тежине универзитетског уџбеничког текста теологије на енглеском и српском језику за перципирање од стране читаоца. Користили смо метод И. Росандић који најпотпуније задовољава потребе анализе датог корпуса. Ради бољег увида, извршили смо и компарацију са степеном тежине академских и научно-популарних радова из области теологије.

Кључне речи: индекс читљивости, фактори тежине, теологија, научноуџбенички текстови, радови академског подстила, радови научно-популарног подстила

0. Екстралингвистичке карактеристике научног, а тиме и теолошког начина мишљења и излагања, поред лексичког и морфолошког, остављају трага и на синтаксичком нивоу научних радова. Научни стил теолошких радова на плану синтаксе не показује значајнија одступања у поређењу са научним радовима генерално, посебно са радовима хуманистичких наука. Међутим, мање или веће разлике од синтаксичких карактеристика и варијације могу се запазити између радова с обзиром на њихову подстилску групу, односно с обзиром на то да ли припадају строго-научном или академском, научноуџбеничком или научно-популарном подстилу. Тако да ће поједини елементи синтаксичког нивоа присутни у радовима строго научног

Православни богословски факултет, Мије Ковачевића 116, Београд 11060 iknezevic@bfspc.bg.ac.rs 
подстила, као основног представника научног стила теологије, бити у мањој или већој мери присутни и у радовима научно-уџбеничког и научно-популарног подстила.

Овим радом даћемо приказ основних карактеристика синтаксе научних радова теологије, а затим ћемо извршити анализу степена читљивости текста на узорцима корпуса осамнаест радова еминентних аутора на српском и енглеском језику. Изабрани радови припадају једном од три подстила научних радова: академском, научно-уџбеничком и научно-популарном, где сваки подстил укључује по три рада. На крају су дате и просечне вредности за научни стил енглеског и српског језика.

1. Концизност и сажетост у изражавању идеја, начин аргументације, указивање на след мисли утичу на доминацију сложених реченица у научном стилу теолошких радова, како енглеског тако и српског језика. Реченице су по правилу комплексне, са великим бројем зависних реченица (подређених клауза). У складу с тим у теолошким радовима присутан је и изузетно квантитативно богат али и разноврстан сет везника, именских предлога и сличних речи организатора излагања, чија је примарна функција да укажу на логичан ток излагања и да овако комплексно и сложено за праћење изражавање мисли што јасније и пластичније представе.

Од зависних реченица најчешће су атрибутске, али и узрочнопоследичне, временске и условне реченице, и оне су процентуално доминантније у односу на независне реченице.

Просте реченице појављују се у знатно мањој мери. Њима се аутори најчешће служе да изведу неки закључак или сумирају претходно излагање, те оне у том смислу олакшавају читање, чине текст прегледнијим, и помажу у перципирању често замршених и комплексно изложених идеја и мисли.

Међутим, степен сложености структуре реченица обрнуто је сразмеран академизму излагања. Наиме, што је текст даљи од академског научног излагања строгог подстила то и сложеност реченичне структуре „опада“. Начин излагања се мења с обзиром на циљни аудиторијум - под тим се подразумева не само згуснута информативност строго научног текста, терминолошка лексика (о чему је већ било речи), већ и начин излагања датих проблема. Аутор научно- 
уџбеничког или научно-популарног дела мора водити рачуна да и саму структуру реченице (а) прилагоди циљној читалачкој публици. Дакле, структура реченице се „упрошћава“. Сложене реченице губе на својој комплексности и вишечланости када су зависне реченице у питању. Ово све утиче и на величину пасуса која се смањује с обзиром на подстил научног текста, јер аутор настоји да и једну мисаону целину учини лакшом за перцепцију, па најчешће и реченице организује у мање групе него што је то најчешће случај у строго научним радовима. Сложеност реченица додатно повећавају и, најчешће секундарне по значају, информације или властити коментари које аутор уноси у реченицу уз употребу заграда, а које тако постају мисао, па и „реченица/реченице за себе“.

Аутори своје излагање износе изјавним реченицама, а ретко ипак користе и упитне и узвичне реченице. Упитне реченице се могу јавити у виду реторских питања чија је улога да пробуде пажњу читаоца, ментално га активирају приликом усвајања датог дела текста скрећући пажњу на важност одређених његових елемената, и тичу се садржаја текста. У случају да питању следи одговор, може се радити о некој врсти замишљеног дијалога између читаоца који питања „поставља“ и аутора који на иста одговара.

С друге стране, овакви комплекси питање-одговор могу имати и монолошки карактер, наиме да аутор сам себи поставља питање, чуди се, износећи тако директно и питања које је сам себи постављао у мисаоно-сазнајном процесу, да би затим изнео и одговоре до којих је дошао. Овакав тип питања уноси живост и разбија монотонију научног излагања, јављајући присуство личности аутора и уносећи ауторску ноту.

Питање које нема реторску ноту, и не следи му одговор, најчешће поставља сам аутор читаоцу и захтева од њега да нађе одговор. Ово је једносмерно питање које се на томе задржава. Ово је посебно присутно у уџбеничком подстилу научних радова.

Узвичне реченице посебно су честе у полемичким списима, бројније су свакако у радовима периферних подстилова научног стила, и имају експресивни карактер.

Елиптичне реченице су изразито непожељан елемент у синтакси научног стила, будући да утичу на јасност и прецизност, али и на формални тон научног излагања. 
Безличност научног излагања утиче и на велики број обезличених реченица као и пасивних конструкција у оба језика. Обезличене реченице „скривају“ агенса радње који је заправо присутан и дају уопштеност и објективност научном исказу.

Безличност се у српском језику постиже и употребом инфинитива и израза „бити потребан“, док ту функцију у енглеском врше инфинитивне, герундивне и партиципске фразе будући да нису показатељи глаголских категорија лица, броја и времена.

Пасивне конструкције, у оба језика, посебно погодују да се неометано износе мисли и идеје, акцентујући проблем-објекат који постаје доминантан заузимајући проминентно место у структури пасивне реченице.

Ред речи у реченици радова научног стила како на српском тако и на енглеском језику је углавном директан. Стандардизованост синтаксичке структуре - редоследа синтаксичких јединица и њихове употребе, олакшава перцепцију комплексног и информационо засићеног садржаја научних радова. Ретко се, међутим, од устаљеног реда речи одступа када је инверзија у реченици неопходна да би се успоставила боља и јаснија логичка повезаност са претходним исказом, да се акцентује одређена мисао, и сл.

2. У настојању да утврдимо степен тежинетекста за перципирање од стране читаоца одабрали смо метод који наводи И. Росандић као онај који најпотпуније задовољава потребе анализе датог корпуса (Rosandić 1988: 73-76). Приликом примене овог метода унели смо извесне измене и допуне које су нужне с обзиром на врсту текстова, наиме с обзиром да је реч о специфичној научној области, тј. научним текстовима из области теологије који, уз то, припадају и различитим подстиловима.

Метод израчунавања степена тежине текста, према Ирени Росандић, узима у обзир одређене фиксне факторе, наиме број речи и број реченица, с једне, и, с друге стране, избор предложених фактора, попут броја неуобичајених, несвакодневних речи, различитих речи, тешких речи, апстрактних речи, дугих речи (изнад 7 слова; према Микк 1975: 147-155), и сл. Након извршене анализе датог текста а на основу добијених података, примењује се формула „индекса читљивости" (LIX) која гласи: 


\section{Култура универзитета и филологија}

индЕКС чИтљивости $=\frac{\text { број речи (a) }}{\text { број реченица (b) }}+\frac{\text { број дугих речи }(\mathbf{c}) * \mathbf{1 0 0}}{\text { број речи (a) }}$

или:

$\mathrm{LIX}=\frac{a}{b}+\frac{c * 100}{a}$

Добијени резултат показује степен тежине текста за читање, с обзиром на одређени фактор, и он је исказан следећом скалом Ренате Шулц (Shulz 1981: 226-254) и то:

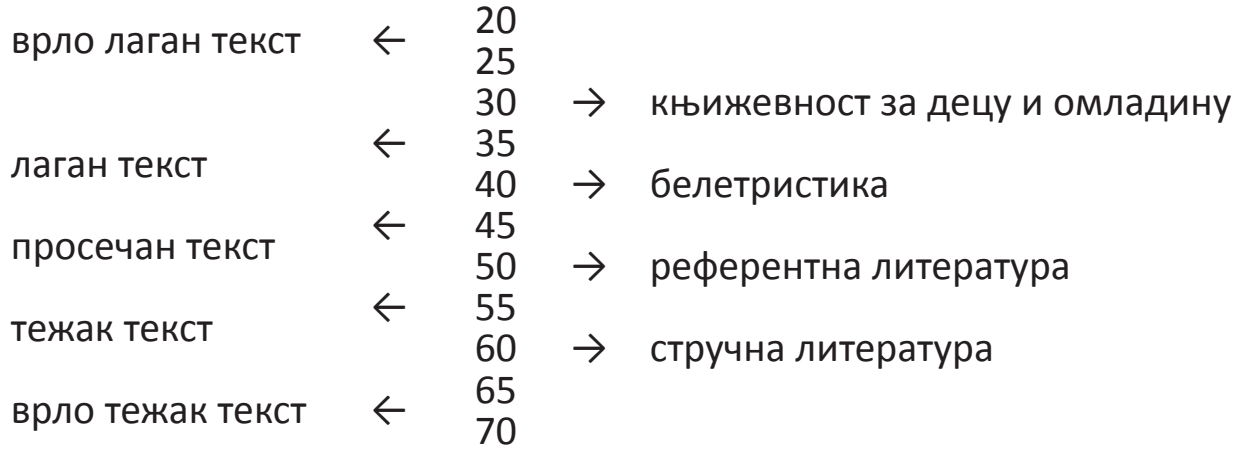

Анализа степена читљивости текста извршена је на узорцима корпуса од осамнаест радова еминентних теолога, на српском и енглеском језику. Изабрани радови припадају једном од три подстила научних радова: академском (строго научном), научно-уџбеничком и научно-популарном, где сваки подстил укључује по три рада.

Сваки од узорака радова садржи 300 речи (а), на основу којих се утврђује и број реченица (b). Од датих фактора у обзир смо узели три предложена, и то: тежину речи, дужину речи и апстрактне речи. Фактори су дефинисани на следећи начин.

Фактор тежине одређен је тиме што је у његов оквир била укључена стручна лексика, као и неуобичајене, несвакидашње речи, а са становишта једног просечног читаоца.

У дуге речи убројане су све речи које садрже изнад седам слова, како у текстовима на српском тако и на енглеском језику. Иако се правила читања не подударају у српском и у енглеском језику, тј. у српском језику сваком слову одговара један глас, што у енглеском није случај, 
ипак је и у радовима на енглеском језику узет у обзир број слова а не, нпр. број слогова, из разлога што то не би на прихватљив начин кореспондирало одговарајућем критеријуму текста на српском језику. Осим тога, читалац текста на енглеском перципира свако појединачно слово написане речи без обзира на њен изговор.

Трећи фактор - апстрактне речи, дефинисан је као такав који обухвата речи које описују нешто неопипљиво, што се замишља или oceћа (в. Станојчић et al, 1989: 79), и које именују све „неконкретне“ појаве, као и оне чија се семантика у датом тексту проширује на управо овакве појаве (попут: идеја, мисао, појам, суштина; или у енглеском: issue, idea, essence).

Сваки од ових фактора примењен на поменути корпус дао је одговарајуће резултате и позиционирао према томе текст на горе наведеној скали. Ми смо, међутим, у датој анализи узели у обзир и њихов просек и тако утврдили, на основу све три појединачне вредности, једну средњу вредност која предлаже место текста на датој скали, како за сваки од текстова посебно на енглеском односно српском језику, тако и просечне вредности за текстове сваког подстила ова два језика појединачно и скупа, и просек свих подстилова ова два језика засебно.

Индекс читљивости текста означен је:

a) с обзиром на фактор тежине речи - LIX ;

б) с обзиром на дужину речи - LIX;

в) с обзиром на апстрактне речи - LIX ; а

г) просечна вредност ова три индекса означена је LIX $_{\Sigma}$.

Поред тога, приликом анализе издвојили смо посебно и вредност која је саставни део формуле, а коју Росандић није посебно анализирао, тј. однос броја речи (300) и броја реченица, или како стоји у формули a/b. Однос ове две вредности показује просечну дужину реченице с обзиром на број речи, што такође утиче на читљивост текста. Наиме, што је дата вредност (a/b) виша, тј. што је реченица дужа (састоји се из више речи), то је и њена перцепција од стране читаоца тежа и компликованија.

С обзиром на дате факторе, истакли бисмо да је и прецизно утврђивање одговарајућих речи које подлежу параметрима узетим у обзир, као и коначни резултат дефинисања степена тежине текста 
за читање релативан и не сасвим прецизан. Наиме, речи и њихово значење у контексту, као и значење и њихова тежина за просечног читаоца, не могу се сасвим прецизно утврдити. Језик се не може, због своје вишеслојне, неухватљиве природе изучавати као егзактна, конкретна појава, већ се на основу одређених параметара, често једнако несавршених у смислу своје прецизне одређености, може добити приближан - али свакако не и прецизан, опис и дефиниција.

У наредном делу изложићемо добијене вредности текстова за научно-уџбенички, строго-научни и научно-популарни подстил. У табелама смо ради боље прегледности користили скраћенице за наслове датог корпуса и то:

1) за радове научно-уџбеничког текста на:

а) српском језику:

УНЗ - Увод у Нови завет, Предраг Драгутиновић;

УСПСЗ -Увод у Свето Писмо Старог Завета, Драган Милин;

СПЦ - Српска православна Црква: прилози за историју 2, Предраг Пузовић;

б) на енглеском језику:

CAS - The Church in the Ancient Society, Henry Chadwick;

SP - St Paul, James D. G. Dunn;

INTOC - An Introduction to the New Testament and the Origins of Christianity, Delbert Burkett

2) за радове строго научних радова на

а) српском језику:

СГП - Личност и суштина у теологији светог Григорија Паламе, Владан Перишић;

ДП - Духовност православља, Атанасије Јевтић;

ЕТЛПВ - Евхаристијска теорија личности и православна веронаука, Богдан Лубардић.

б) енглеском језику:

$\mathrm{NTI}$ - The New Testament: Introduction, Paul Nadim Tarazi;

OWS - Of Water and the Spirit, Alexander Schmemann;

BLOC - The Byzantine Legacy in the Orthodox Church, John Meyendorff.

3) за радове научно-уџбеничког подстила на:

а) српском језику:

РПВ - Разговори са професорима о вери, Лазар Милин; 
ПК - Православни катихизис, Данило Крстић и Амфилохије Радовић;

ЉВЗБ - Љубав - врховни закон бића, Данило Крстић; In: Теолошки погледи: веронаучни часопис.

б) енглеском језику:

OFD - The Orthodox Faith: Doctrine, Thomas Hopko;

HRB - How to Read the Bible, Kallistos Ware; [http://www.oca.org/ Docs.asp?ID $=180 \& S I D=2]$

LP - Living Prayer, Anthony Bloom.

Следе табеларни прикази и анализе поменутих вредности за:

1. сваки појединачни рад научно-уџбеничког подстила:

а) ЕНГЛЕСКОГ ЈЕЗИКА

\begin{tabular}{|c|c|c|c|c|c|}
\hline & $\mathrm{a} / \mathrm{b}$ & $\mathrm{LIX}_{1}$ & $\mathrm{LIX}_{2}$ & $\mathrm{LIX}_{3}$ & $\mathrm{LIX}_{\Sigma}$ \\
\hline $\mathrm{CAS}$ & 22 & $+17=39$ & $+15=37$ & $+19=41$ & 39 \\
\hline $\mathrm{INTOC}$ & 23 & $+21=44$ & $+12=35$ & $+17=40$ & 40 \\
\hline $\mathrm{SP}$ & 27 & $+40=67$ & $+28=55$ & $+32=59$ & 60 \\
\hline $\begin{array}{c}\text { просечне } \\
\text { вредности }\end{array}$ & 24 & 50 & 42 & 47 & 46 \\
\hline
\end{tabular}

б) СРПСКОГ ЈЕЗИКА

\begin{tabular}{|c|c|c|c|c|c|}
\hline & $\mathrm{a} / \mathrm{b}$ & $\mathrm{LIX}_{1}$ & $\mathrm{LIX}_{2}$ & $\mathrm{LIX}_{3}$ & $\mathrm{LIX}_{\Sigma}$ \\
\hline УH3 & 21 & $+26=47$ & $+25=46$ & $+35=56$ & 50 \\
\hline УСПСЗ & 19 & $+39=58$ & $+25=44$ & $+35=54$ & 52 \\
\hline СПЦ & 20 & $+32=52$ & $+19=39$ & $+27=47$ & 46 \\
\hline $\begin{array}{c}\text { просечне } \\
\text { вредности }\end{array}$ & 20 & 52 & 43 & 52 & 49 \\
\hline
\end{tabular}

2. просек свих радова научно-уџбеничког подстила за оба језика

\begin{tabular}{|c|c|c|c|c|c|}
\hline & $\mathrm{a} / \mathrm{b}$ & $\mathrm{LIX}_{1}$ & $\mathrm{LIX}_{2}$ & $\mathrm{LIX}_{3}$ & $\mathrm{LIX}_{\Sigma}$ \\
\hline $\begin{array}{c}\text { научно- } \\
\text { уџбенички }\end{array}$ & 22 & 51 & 42 & 49 & 48 \\
\hline
\end{tabular}


На основу приказаних резултата запажамо да је просечна дужина реченице у уџбеничким текстовима нешто већа у енглеском језику и износи 24, док је у српском 20, за разлику од строго научних текстова где је разлика између ове вредности изразита (34:23). Аутори уџбеника морају да поведу више рачуна о циљној читалачкој публици (студентима, у нашем случају) и свој рад учине доступнијим па у том смислу и лакше читљивим, док је њихова слобода у стварању научних радова далеко већа када је реч о строго научним радовима, где ауторски печат више долази до изражаја, што се огледа и у начину изражавања мисли у смислу дужине реченица, тј. читљивости.

Индекс читљивости с обзиром на фактор дужине речи, и у уџбеницима као и у строго научним радовима, готово је изједначен у енглеском и српском језику (42:43) што ове радове поставља између лаганог и просечног текста. Друге две вредности, LIX $_{1}$ и LIX $_{3}$, нешто су више у уџбеницима на српском језику (52 и 52), што их дефинише као средње тежак текст. У енглеском језику добијене цифре (50 и 47), одређују их као средње тешке, односно просечне текстове. Просек ова три фактора за српски језик, следствено томе, виши је у радовима на српском (49), што их поставља између просечног и тешког текста, него што је то случај са радовима на енглеском језику (46), који су ближи просечном тексту.

Следе табеларни прикази и анализе поменутих вредности за радове академског подстила:

1. сваки појединачни рад строго научног подстила:

а) ЕНГЛЕСКОГ ЈЕЗИКА

\begin{tabular}{|l|c|c|c|c|c|}
\hline & $\mathrm{a} / \mathrm{b}$ & $\mathrm{LIX}_{1}$ & $\mathrm{LIX}_{2}$ & $\mathrm{LIX}_{3}$ & $\mathrm{LIX}_{\Sigma}$ \\
\hline $\mathrm{BLOC}$ & 37,5 & $+29=67$ & $+22=60$ & $+21=59$ & 62 \\
\hline OWS & 33 & $+21=54$ & $+15=48$ & $+24=57$ & 53 \\
\hline NTI & 30 & $+29=59$ & $+14=44$ & $+27=57$ & 54 \\
\hline $\begin{array}{l}\text { просечне } \\
\text { вредности }\end{array}$ & 34 & 60 & 51 & 57 & 56 \\
\hline
\end{tabular}


б) СРПСКОГ ЈЕЗИКА

\begin{tabular}{|l|c|c|c|c|c|}
\hline & $\mathrm{a} / \mathrm{b}$ & $\mathrm{LIX}_{1}$ & $\mathrm{LIX}_{2}$ & $\mathrm{LIX}_{3}$ & $\mathrm{LIX}_{\Sigma}$ \\
\hline$Д П$ & 22 & $+23=45$ & $+28=50$ & $+34=56$ & 51 \\
\hline СГП & 27 & $+41=68$ & $+27=54$ & $+53=81$ & 68 \\
\hline ЕТЛПВ & 22 & $+28=50$ & $+26=48$ & $+40=62$ & 53 \\
\hline $\begin{array}{l}\text { просечне } \\
\text { вредности }\end{array}$ & 23 & 54 & 51 & 66 & 57 \\
\hline
\end{tabular}

2. просек свих радова строго научног подстила за оба језика

\begin{tabular}{|l|c|c|c|c|c|}
\hline & $\mathrm{a} / \mathrm{b}$ & $\mathrm{LIX}_{1}$ & $\mathrm{LIX}_{2}$ & $\mathrm{LIX}_{3}$ & $\mathrm{LIX}_{\Sigma}$ \\
\hline $\begin{array}{l}\text { строго } \\
\text { научни }\end{array}$ & 29 & 57 & 51 & 62 & 56,5 \\
\hline
\end{tabular}

Према приказаним резултатима анализе запажамо да је у текстовима на енглеском језику вредност a/b, односно просечна дужина реченице с обзиром на број речи знатно виша него у истим на српском језику (у просеку 34:23). Индекс читљивости с обзиром на тежину речи, такође је нешто виши у радовима на енглеском језику (60:54), и поставља их између тешког и врло тешког текста, а ове друге дефинише као тежак текст. С друге стране, с обзиром на фактор апстрактности случај је обрнут, наиме виши је у текстовима на српском језику (57:66), што их дефинише као врло тежак текст, а радове на енглеском поставља између тешког текста и врло тешког. Индекс читљивости је сасвим изједначен у оба језика када је у питању дужина речи (51, или средње тежак текст), а готово изједначен када се у обзир узме просек три поменута фактора (56:57), што их поставља између тешког и врло тешког текста, како сваки понаособ тако и просечно радове оба језика строго научног стила $(56,5)$.

На крају, приказујемо и табеле и анализе поменутих вредности за радове научно-популарног подстила. 
1. појединачни радови научно-популарног подстила:

а) ЕНГЛЕСКОГ ЈЕЗИКА

\begin{tabular}{|l|c|c|c|c|c|}
\hline & $\mathrm{a} / \mathrm{b}$ & $\mathrm{LIX}_{1}$ & $\mathrm{LIX}_{2}$ & $\mathrm{LIX}_{3}$ & $\mathrm{LIX}_{\Sigma}$ \\
\hline $\mathrm{HRB}$ & 18 & $+24=42$ & $+17=35$ & $+23=41$ & 39 \\
\hline $\mathrm{LP}$ & 25 & $+25=50$ & $+9=34$ & $+27=52$ & 45 \\
\hline OFD & 20 & $+27=47$ & $+10=30$ & $+26=46$ & 41 \\
\hline $\begin{array}{l}\text { просечне } \\
\text { вредности }\end{array}$ & 21 & 46 & 33 & 46 & 42 \\
\hline
\end{tabular}

б) СРПСКОГ ЈЕЗИКА

\begin{tabular}{|l|c|c|c|c|c|}
\hline & $\mathrm{a} / \mathrm{b}$ & $\mathrm{LIX}_{1}$ & $\mathrm{LIX}_{2}$ & $\mathrm{LIX}_{3}$ & $\mathrm{LIX}_{\Sigma}$ \\
\hline ПК & 11 & $+7=28$ & $+11=22$ & $+13=24$ & 25 \\
\hline РПВ & 30 & $+16=46$ & $+17=47$ & $+15=45$ & 46 \\
\hline ЉВ3Б & 33 & $+26=59$ & $+16=49$ & $+30=63$ & 57 \\
\hline $\begin{array}{l}\text { просечне } \\
\text { вредности }\end{array}$ & 25 & 43 & 39 & 44 & 43 \\
\hline
\end{tabular}

2. просек свих радова научно-популарног подстила за оба језика:

\begin{tabular}{|l|c|c|c|c|c|}
\hline & $\mathrm{a} / \mathrm{b}$ & $\mathrm{LIX}_{1}$ & $\mathrm{LIX}_{2}$ & $\mathrm{LIX}_{3}$ & $\mathrm{LIX}_{\Sigma}$ \\
\hline $\begin{array}{l}\text { научно- } \\
\text { популарни }\end{array}$ & 23 & 45 & 36 & 45 & 42,5 \\
\hline
\end{tabular}

Из горе наведених података примећује се да је реченица просечно краћа у радовима на енглеском него на српском језику (21:25). Просечни индекс читљивости с обзиром на тежину речи виши је у радовима на енглеском (46:43), што их чини просечним текстом, док су радови на српском између лаганог и просечног текста. Слично је и са индексом када је у питању апстрактност речи (46:44). У радовима на српском у просеку, међутим, користе се нешто дуже речи и овај однос износи 39:33, што их приближава просечном, а радове на енглеском језику лаганом тексту. Ипак, просек ова три индекса готово је изједначен у оба језика и износи у енглеском 42, а у српском 43, чиме су позиционирани између лаганих и просечних текстова. 
Следе табеларни прикази и анализе поменутих просечних вредности радова за научни стил енглеског и српског језика:

а) НАУЧНИ СТИЛ ЕНГЛЕСКОГ ЈЕЗИКА

\begin{tabular}{|l|c|c|c|c|c|}
\hline енглески језик & $\mathrm{a} / \mathrm{b}$ & $\mathrm{LIX}_{1}$ & $\mathrm{LIX}_{2}$ & $\mathrm{LIX}_{3}$ & $\mathrm{LIX}_{\Sigma}$ \\
\hline строго научни & 34 & 60 & 51 & 57 & 56 \\
\hline научно-уџбенички & 24 & 50 & 42 & 47 & 46 \\
\hline научно- популарни & 21 & 46 & 33 & 46 & 42 \\
\hline просечне вредности & 26 & 52 & 42 & 50 & 48 \\
\hline
\end{tabular}

б) НАУЧНИ СТИЛ СРПСКОГ ЈЕЗИКА

\begin{tabular}{|l|c|c|c|c|c|}
\hline српски језик & $\mathrm{a} / \mathrm{b}$ & $\mathrm{LIX}_{1}$ & $\mathrm{LIX}_{2}$ & $\mathrm{LIX}_{3}$ & $\mathrm{LIX}_{5}$ \\
\hline строго научни & 23 & 54 & 51 & 66 & 57 \\
\hline научно-уџбенички & 20 & 52 & 43 & 52 & 49 \\
\hline научно- популарни & 25 & 43 & 39 & 44 & 43 \\
\hline просечне вредности & 23 & 50 & 44 & 54 & 50 \\
\hline
\end{tabular}

В) СРЕДЊА ВРЕДНОСТ НАУЧНОГ СТИЛА ЗА ОБА ЈЕЗИКА

\begin{tabular}{|l|c|c|c|c|c|}
\hline & $\mathrm{a} / \mathrm{b}$ & LIX $_{1}$ & LIX $_{2}$ & LIX $_{3}$ & LIX $_{5}$ \\
\hline $\begin{array}{l}\text { просечне средње } \\
\text { вредности }\end{array}$ & $\mathbf{2 5}$ & $\mathbf{5 1}$ & $\mathbf{4 3}$ & $\mathbf{5 2}$ & $\mathbf{4 9}$ \\
\hline
\end{tabular}

Како се из изложеног може приметити, вредности индекса читљивости теолошких радова научног стила уопште у енглеском и у српском језику врло су сличне, па је стога изведена и средња вредност која радове сва три подстила научног стила у теологији поставља између просечног и тешког текста.

3. Узимајући у обзир просечне вредности радова на енглеском и српском језику, из наведене анализе може се закључити да је научноуџбенички текст је с обзирома на дужину реченице (22) ближи научно-популарним радовима (23), него академским $(28,5)$. Према тежини речи (51) налази се између радова остала два подстила (академски 51, научно-популарни 45). Исти је случај и у вези са фактором дужине речи (42,5:51:36). Ипак, када је реч о апстрактним речима, запажа се да су уџбеници из области теологије (49) приметно ближи науч- 
но-популарним радовима (45), него академским (62). Дакле, аутори уџбеника воде рачуна о читалачкој публици и настоје да студентима олакшају перцепцију употребом краћих реченица и мањим бројем апстрактних речи, али користећи краће и познате речи.

Поредећи уџбенике на енглеском и српском језику, запажамо да су реченице у просеку нешто дуже у текстовима на енглеском језику (24:20), али је употреба апстрактних речи нешто већа у уџбеницима на српском језику (47:52). Остале две вредности, тежина и дужина речи, приближно су сличне (50:52 и 42:43). Узимајући у обзир три фактора (LIX ${ }_{1}$, LIX $_{2}$, LIX $\left._{3}\right)$ изводимо закључак да се уџбеници теологије на српском језику (49) налазе готово између просечног и тешког текста, за разлику од уџбеника на енглеском (46) који припадају тексту просечне тежине, а чак нагињу и лаганим текстовима.

\section{Литература}

Микк, Я. А. Методика измерения трудности текста. - Вопросы психологии, № 3, 1975: 147-155.

Станојчић, Ж., Љ. Поповић и С. Мицић. Савремени српскохрватски језик и култура изражавања. Нови Сад: Завод за уџбенике и наставна средства, Београд: Завод за издавање уџбеника, 1989. Штампано.

Rosandić, Irena. Tekst u nastavi njemačkog kao stranog jezika. Doktorska disertacija. Zagreb: Sveucilište u Zagrebu, Filozofski fakultet, 1988. Штампано.

Shulz, R. Literature and Readibility: Bridging the Gap in Foreign Language Reading. In: Lesen in der Fremdsprache. Munchen: Goethe-Institut, 1981: 226-254. Штампано.

\section{Извори}

\section{Корпус на енглеском језику}

Bloom, Anthony. Living Prayer. Springfield, IL: Templegate Publishers, 1966. Штампано. Burkett, Delbert. An Introduction to the New Testament and the Origins of Christianity. Cambridge: Cambridge University Press, 2002. Штампано.

Chadwick, Henry. The Church in the Ancient Society: From Galilee to Gregory the Great. Oxford: Oxford University Press, 2003. Штампано.

Dunn, James D. G. (The Cambridge Companion to) St Paul. Cambridge: Cambridge University Press, 2003. Штампано. 
Hopko, Thomas. The Orthodox Faith: Doctrine. New York: The Department of Religious Education - Orthodox Church in America, 1976. Штампано.

Meyendorff, John. The Byzantine Legacy in the Orthodox Church. New York: St Vladimir's Seminary Press, 1982. Штампано.

Schmemann, Alexander. Of Water and the Spirit. New York: St Vladimir's Seminary Press, 1974. Штампано.

Tarazi, Paul Nadim. The New Testament: An Introduction. New York: St Vladimir's Seminary Press, 1999. Штампано.

Ware, Kalistos. How to Read the Bible. [http://www.oca.org/Docs.asp?ID=180\&SID=2]

\section{Корпус на српском језику}

Драгутиновић, Предраг. Увод у Нови завет: Основи новозаветне веронауке. Београд: Православни богословски факултет - Институт за теолошка истраживања, 2010. Штампано.

Јевтић, Атанасије. Духовност православља. Београд: Храст, 1990. Штампано.

Крстић, Д. и А. Радовић. Православни катихизис. Београд: Хришћанска мисао, 2003. Штампано.

Крстић, Д. „љубав - врховни закон бића“. Теолошки погледи: веронаучни часопис, година 4, бр. 1. Београд: Архиепископија београдско-карловачка, 1971. 1-3. Штампано.

Лубардић, Богдан. „Евхаристијска теорија личности и православна веронаука“. Богословље, год. LXV (LIX), бр. 1-2. Београд: Православни богословски факултет, 2001. 49-105. Штампано.

Милин, Драган. Увод у Свето писмо Старог завета. Београд: Свети архијерејски синод Српске православне цркве, 1991. Штампано.

Милин, Лазар. Разговори са професорима о вери: Апологетска читанка 3. Београд: Свети архијерејски синод Српске православне цркве, 1991. Штампано.

Перишић, Владан. „Личност и суштина у теологији светог Григорија Паламе“. Свети Григорије Палама у историји и садашњости. Србиње: Духовна академија Светога Василија Острошког, 2001. 41-50. Штампано. Штампано.

Пузовић, Предраг. Српска Православна Црква: прилози за историју, књига 2. Београд: Богословски факултет Српске Православне Цркве, 2000. Штампано. 
Ivana Knežević

\section{ANALYSIS OF THE DEGREE OF DIFFICULTY OF UNIVERSITY TEXTBOOK TEXTS OF THEOLOGY IN ENGLISH AND SERBIAN}

\section{Summary}

With this work we tried to determine the degree of difficulty of university textbook texts in the field of theology in English and Serbian for perception by the reader. We used the method of I. Rosandić, which most fully meets the needs of the analysis of the given corpus. For a better insight, we made a comparison with the degree of difficulty of academic and scientific popular papers in the field of theology.

Key words: readability index, factors of difficulty, theology, university textbooks, academic papers, scientific popular papers. 